\title{
A COMBINATION OF FIRE AND DISPERSION MODELING TECHNIQUES FOR SIMULATING A WAREHOUSE FIRE
}

\author{
A. DALY ${ }^{1}$, P. ZANNETTI ${ }^{1} \&$ T. ECHEKKI ${ }^{2}$ \\ ${ }^{1}$ The EnviroComp Institute, Fremont, California, USA. \\ ${ }^{2}$ North Carolina State University, North Carolina, USA.
}

\begin{abstract}
Understanding the environmental impact of large warehouse fires can be a daunting task because of uncertainty in establishing a fire scenario and additional uncertainty about the fate of the fire plume and its content. A warehouse in New Orleans, Louisiana, had a large fire on May 14, 2004. In order to estimate ground-level exposure in the neighborhood of the warehouse, a fire scenario was development and, subsequently, two modeling techniques for the fire plume dispersion were implemented. First, we applied the National Institute of Standards and Technology (NIST) fire model ALOFT-FT to calibrate the smoke emissions (and consequently the emissions of $\mathrm{PM}_{25}$ ). Second, we used US Environmental Protection Agency (EPA) dispersion models (ISCST3 and AERMOD) to calculate the ground-level concentration of smoke from the fire. Because of the high heat of the fire, we estimated that only $6 \%$ or less of the fire emissions could impact the local neighborhood, while $94 \%$ or more of the fire emissions remained high above the ground. For AERMOD, the corresponding percentages are $8 \%$ and $92 \%$. Keywords: AERMOD, accident reconstruction, air quality modeling, ALOFT-FT, fire modeling, ISCST3, plume modeling.
\end{abstract}

\section{INTRODUCTION AND BACKGROUND}

The Advanced Commercial Contracting warehouse at 2740 Arts St., New Orleans, Louisiana, had a 6-alarm fire that started after 6:00 PM local time on May 14, 2004, and lasted through the early morning of May 15, 2004. The fire brought a class action litigation of local residents alleging exposure to air emissions.

We were asked to investigate the fire, identify the chemicals of concern that could have affected the community, and calculate the possible concentration impact at ground level for the chemicals produced by the fire. A law firm retained our services to render our own analysis and opinion on the scientific aspects of the case and, in particular, on the possible inhalation of chemicals by residents during the fire.

The present study reports on results from the analysis of the impact of the Arts Street warehouse fire on the emission in the area surrounding the warehouse. The analysis results in computations of the emitted pollutants, namely particulate matter, $\mathrm{PM}_{2.5}$. The analysis required first an estimate of the rate of release of $\mathrm{PM}_{2.5}$ from the fire. The second step involved the computation of the dispersion of $\mathrm{PM}_{2.5}$ in the immediate neighborhood of the fire using the EPA's AERMOD code. A crucial step involved in this latter computation involves the determination of the fraction of the fire plume that remained near the ground and the remaining fraction that rose much higher because of the fire intensity. This involved the use of a second model using the National Institute of Standards and Technology's (NIST) ALOFT-FT code.

The US Environmental Protection Agency (EPA) has developed and tested air pollution dispersion models (e.g. ISCST3 and AERMOD) that are suitable for simulating the plume rise of emissions from stacks and the physical phenomena associated with transport and dispersion of chemicals in the atmosphere. However, a large fire cannot be simulated as an industrial stack. Therefore, as discussed below, we also used the fire model ALOFT-FT to calibrate the emissions rates of combustion products. 


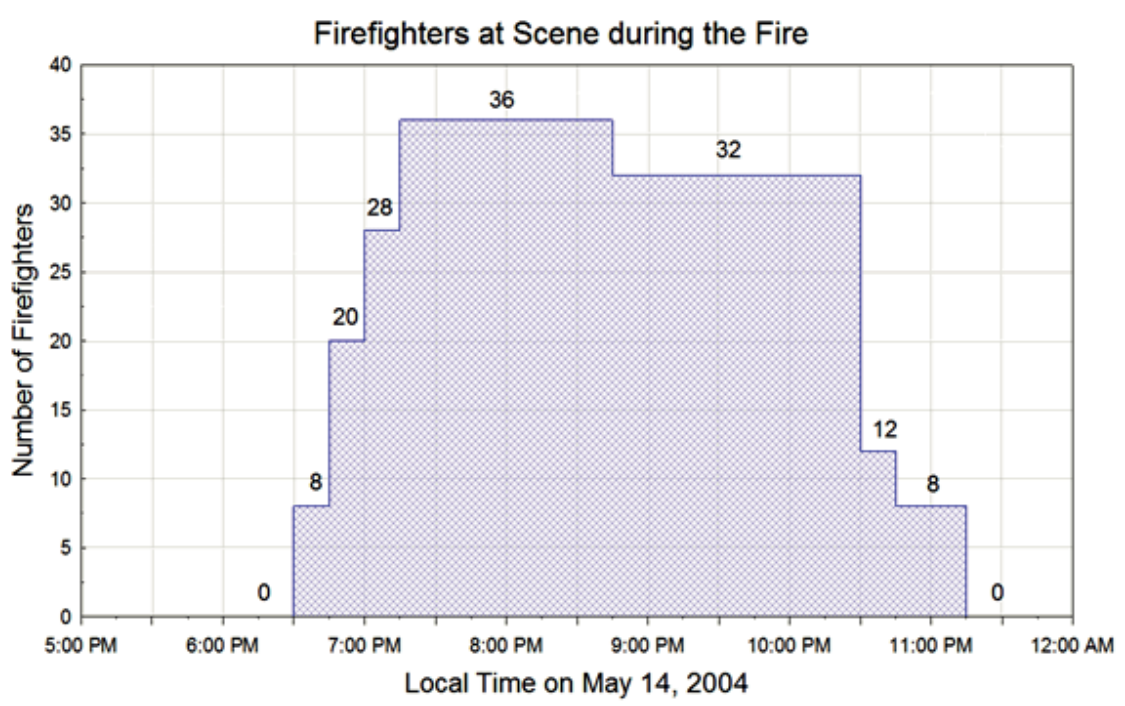

Figure 1: Firefighters at the scene according to the incident reports.

\section{INCIDENT REVIEW AND EMISSION CALCULATIONS}

We collected all available information about the incident, including the official reports of the firefighters at the scene. Despite the availability of some news footage of the Arts Street fire and the fire investigation reports identifying the fire origin, there was still little information to develop a complete scenario of the fire development in the warehouse. Therefore, we have adopted an alternative strategy to estimate the fire scenario. We assumed that the growth and decay of the fire was proportional to the number of firefighters at the scene. The number of fire engines was assumed to be a direct indication of the severity of the fire and its intensity. Fire engines were called as the need for more firefighting power was identified, and fire engines were called back to their stations when the intensity of the fire died down. The number of firefighters, as the fire evolved in the warehouse, as a function of time is shown in Fig. 1.

The firefighter timeline was modified to produce a smoother curve in 15-minute intervals using the natural growth and decay of a fire, as illustrated in Fig. 2.

Then, the curve is normalized in order to scale the growth and decay of fire attributes as shown in Fig. 3. The normalized curve shows the hour of peak fire strength is from 7:30-8:30 PM.

The first scaled fire attribute is the fire size. We estimated the warehouse area to be about $40,000 \mathrm{ft}^{2}\left(3,700 \mathrm{~m}^{2}\right)$ and assumed that at the peak of the incident (7:30-8:30 PM), half of the warehouse was on fire $\left(1,848 \mathrm{~m}^{2}\right)$. The scaling factors depicted in Fig. 3 can be used to estimate the fire size at other times.

The fire curve alone does not provide the full scenario of emissions from the fire. It is used to estimate the distribution of the emission of the fire once the total amount of pollutants is known. This total amount is evaluated by first identifying the amount of combustible material burnt in the fire, then, evaluating the pollutants' emissions by using a conversion via an emission factor. An emission factor indicates the amount of pollutants released during the release of one unit (usually per mass or per energy content) of combustible material involved in a fire.

Based upon available documents, ${ }^{1}$ we estimated that the total amount of wood in the warehouse was about 190,000 kg, and assumed that the amount of burned wood was approximately

1 Inventory Records provided by the client. 


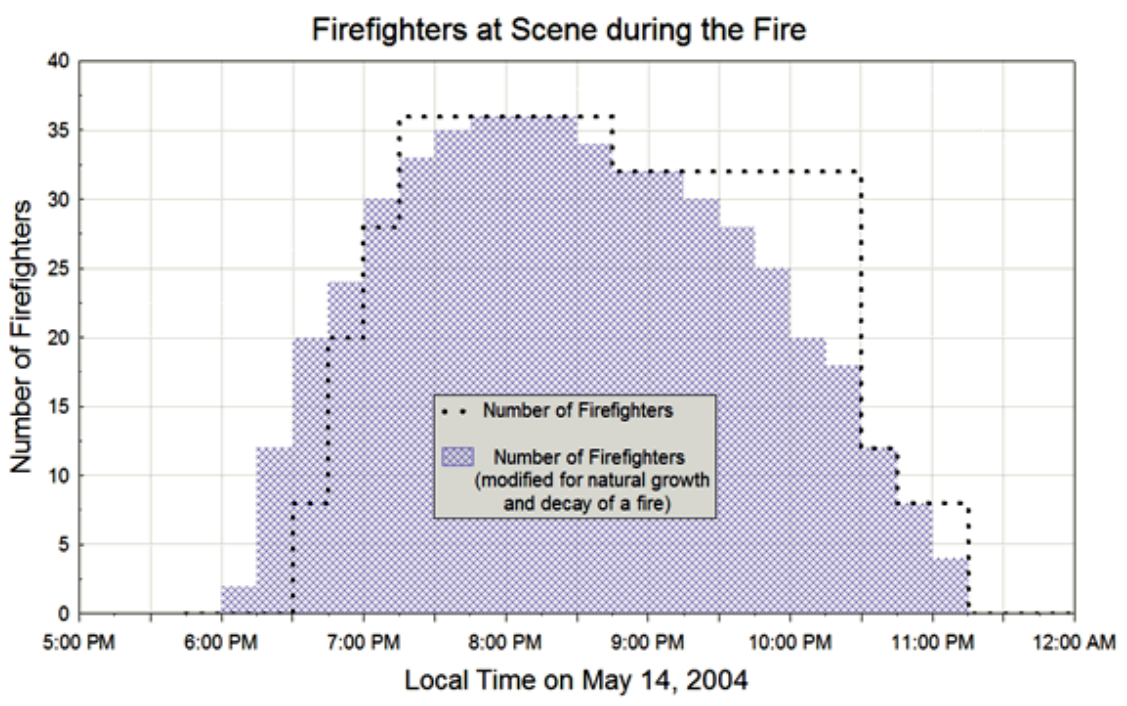

Figure 2: Modified timeline in 15-minute intervals.

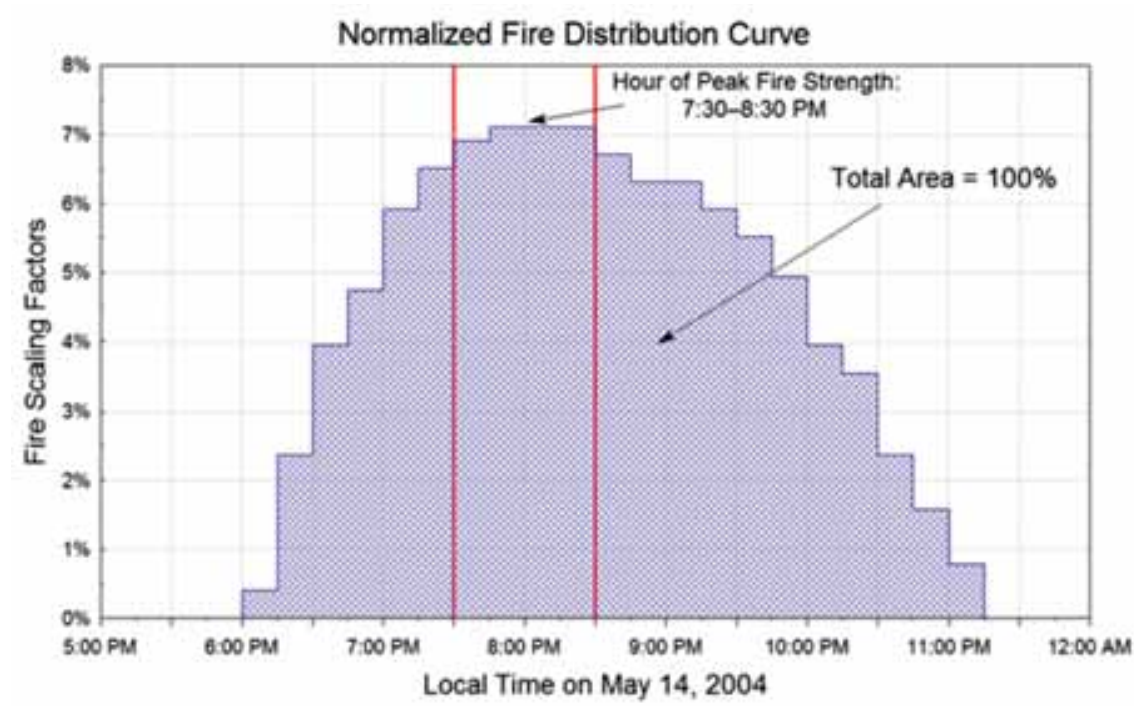

Figure 3: Normalized fire distribution curve.

half of the total; i.e. $95,000 \mathrm{~kg}$. Wood stored in the warehouse is considered the primarily combustible material involved in the fire and on which all emission estimates of $\mathrm{PM}_{2.5}$ are based.

Using the AP-42 document (a set of semi-empirical formulas that calculate emission rates for many industrial, transportation, and activity scenarios) [1], we were able to calculate the emission factor for $\mathrm{PM}_{2.5}$, i.e. the fine particles of size $2.5 \mu \mathrm{m}$ or less emitted during the fire:

$$
\mathrm{PM}_{2.5} \text { Emission factor (AP-42): } \frac{0.310 \mathrm{lbs}^{\mathrm{PM}} \mathrm{P}_{2.5}}{\text { MMBTU of dry wood }}
$$


By assuming the higher heating value for wood to be $8,000 \mathrm{BTU} / \mathrm{lb}$, we derived an emission factor of 2.48 grams of $\mathrm{PM}_{25}$ per each kilogram of wood burned.

Therefore, we estimated that the total $\mathrm{PM}_{2.5}$ released was about $236 \mathrm{~kg}$, which was scaled over each 15-minute interval using the normalized fire scaling values in Fig. 3.

\section{DESCRIPTION OF THE LOCAL CONDITIONS DURING THE FIRE FOR AIR DISPERSION CALCULATIONS}

Figure 4 shows the location of the warehouse in New Orleans, Louisiana, along with the prevailing wind measured at the New Orleans Lakefront Airport [2] at 7:53 pm Local Time. This wind measurement of 11 knots from Southeast describes the local surface winds transporting the plume when the fire was largest (7:30-8:30 PM).

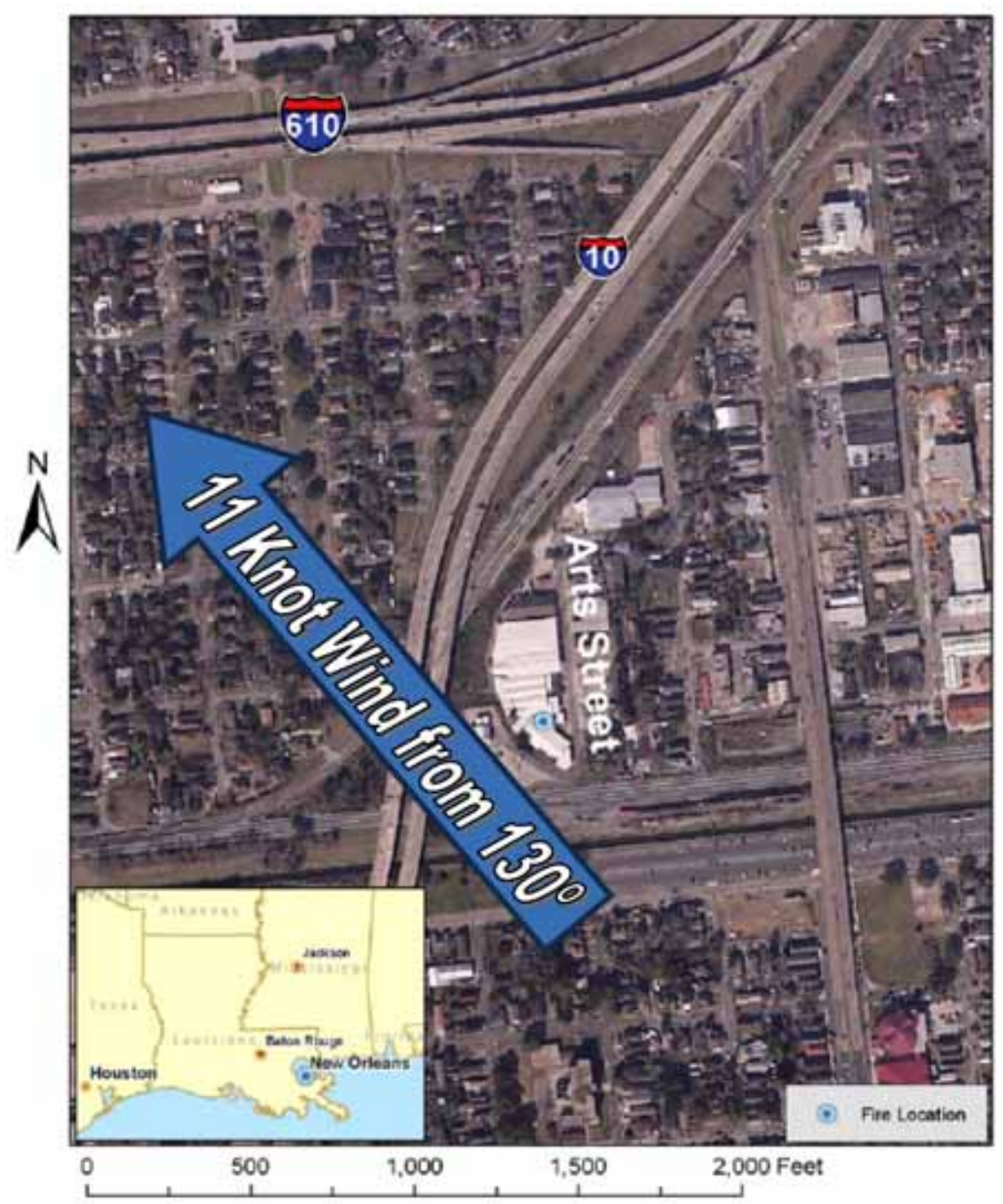

Figure 4: Location of the warehouse fire and prevailing winds during the hour with largest fire emissions (7:30-8:30 PM local time). 
For the purposes of air quality modeling, we classified this area as urban with flat terrain close to sea level.

\section{AIR DISPERSION CALCULATIONS}

We started our simulation modeling work using the ALOFT-FT fire model developed by the NIST. ALOFT-FT is a computer based model to predict the downwind 3-D distribution of smoke particulate and combustion products from large outdoor fires. The output grid is oriented in a downwind-crosswind coordinate system, and the grid points are chosen automatically to simplify the calculations. A portion of our surface grid along with the fire areas are shown in Fig. 5.

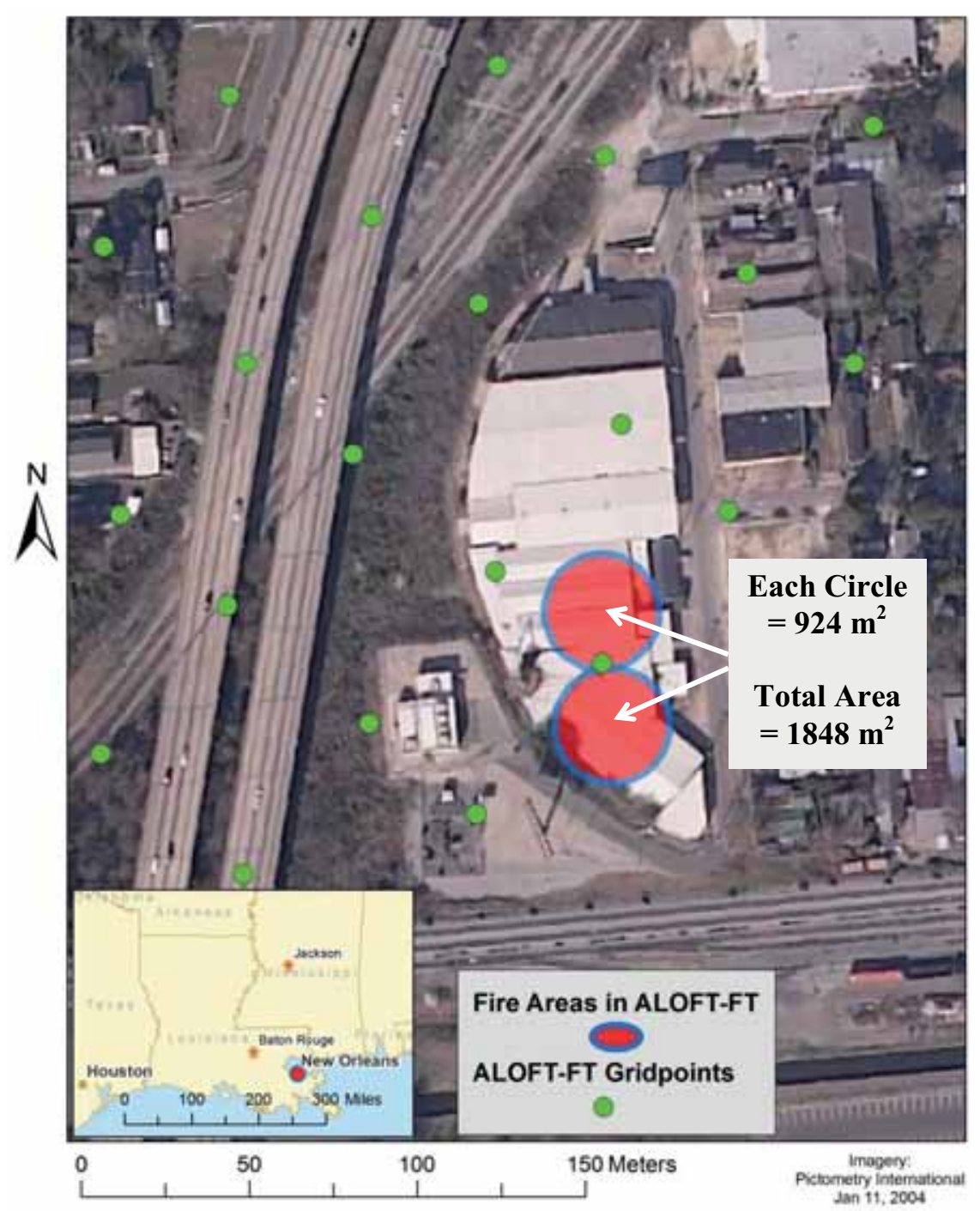

Figure 5: Source areas and gridded receptors used in ALOFT-FT. 


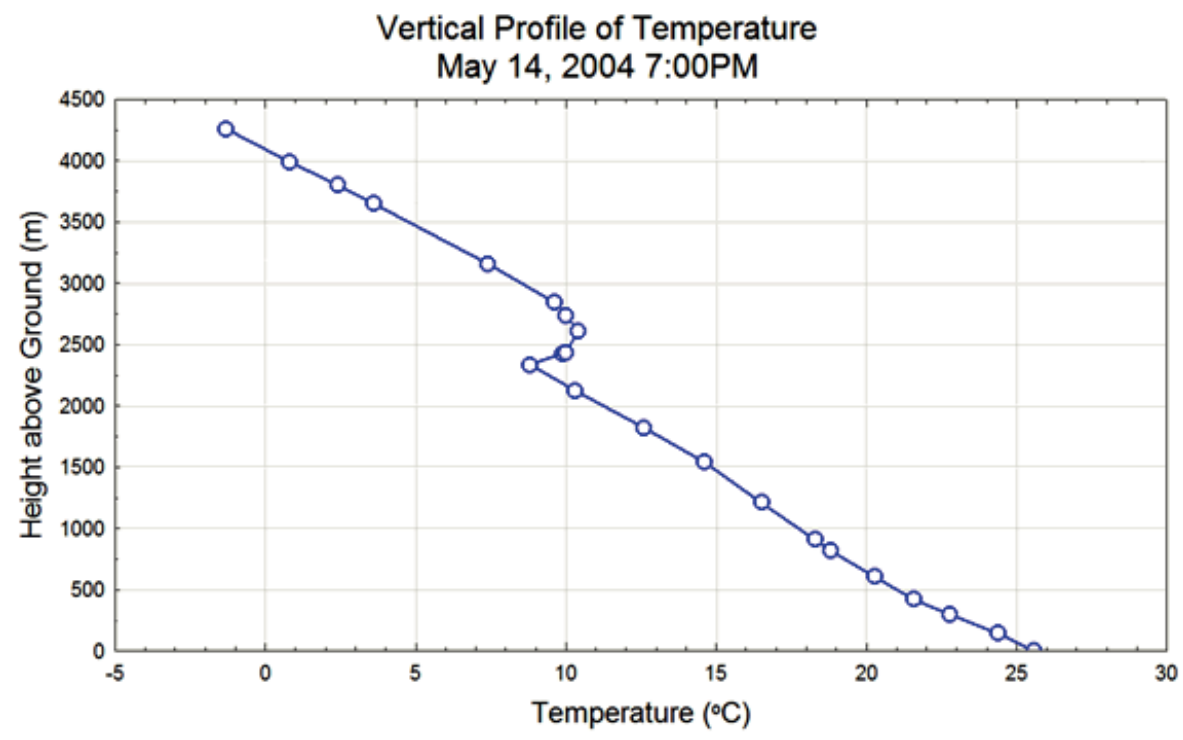

Figure 6: Vertical temperature profile used in our simulation.

We ran the model with the following assumptions and input data:

- Heat Release Rate: 0.26 MW/m² for wood [3].

- Radiative Fraction ${ }^{2}$ (fire energy lost to radiation, does not heat air): $10 \%$

- Fire Area: 1,848 $\mathrm{m}^{2}$ (max hourly average value from 7:30-8:30 PM), divided equally between two circular areas ${ }^{3}$ (see Fig. 5)

- Fuel Consumption Rate per Unit Area: $0.00404 \mathrm{~kg} / \mathrm{m}^{2}-\mathrm{s}$

- $\mathrm{PM}_{2.5}$ Emissions Rate per Unit Area: $0.01002 \mathrm{~g} / \mathrm{m}^{2}-\mathrm{s}$

The fuel consumption rate per unit area is calculated by different the fuel consumption rate, $7.47 \mathrm{~kg} / \mathrm{s}$, by the burning area, $1,848 \mathrm{~m}^{2}$. The $\mathrm{PM}_{2.5}$ emission rate per unit area is calculated as the product of the $\mathrm{PM}_{2.5}$ emission factor, $2.48 \mathrm{~g} / \mathrm{kg}$ of wood, and the fuel consumption rate per unit area resulting in a value of $0.01002 \mathrm{~g} / \mathrm{m}^{2}-\mathrm{s}$.

We used the following meteorological parameters to run ALOFT-FT for the hour of 7:30-8:30 PM May 14, 2004 [2]:

- Surface wind: 11 knots $(5.7 \mathrm{~m} / \mathrm{s})$, blowing from $130^{\circ}$ (from the South-East)

- Pasquill-Gifford stability: D - Neutral.

- Vertical temperature profile: evening radiosonde data from nearby Slidell Airport [4] at 0Z May 15, 2004, as shown in Fig. 6.

Using ALOFT we were able to calculate 1-hour $\mathrm{PM}_{2.5}$ concentrations over a threedimensional domain, as illustrated in Fig. 7. It is important to note that the ALOFT-FT output is qualitatively similar to news footage [5] shown for example in Fig. 8.

2 Default value in ALOFT-FT.

3 The maximum allowed size of a single fire in ALOFT-FT is $1,000 \mathrm{~m}^{2}$. 


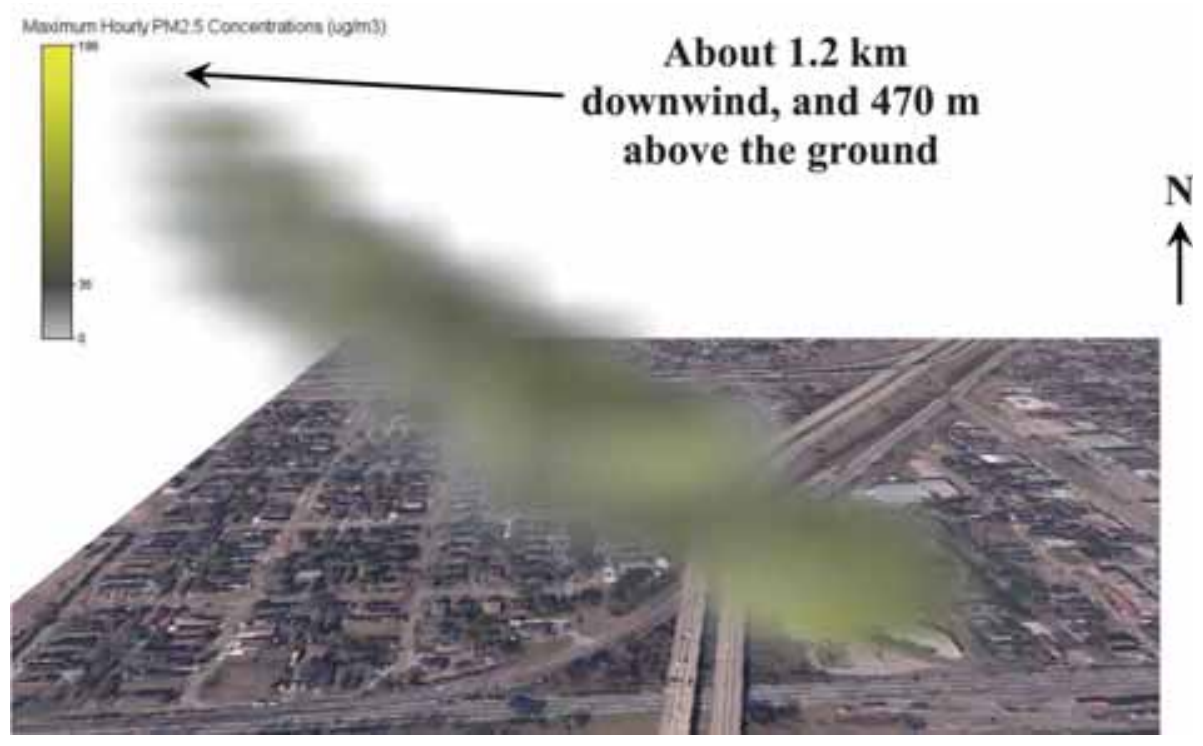

Figure 7: ALOFT-FT hourly $\mathrm{PM}_{2.5}$ concentrations for 7:30-8:30 PM.

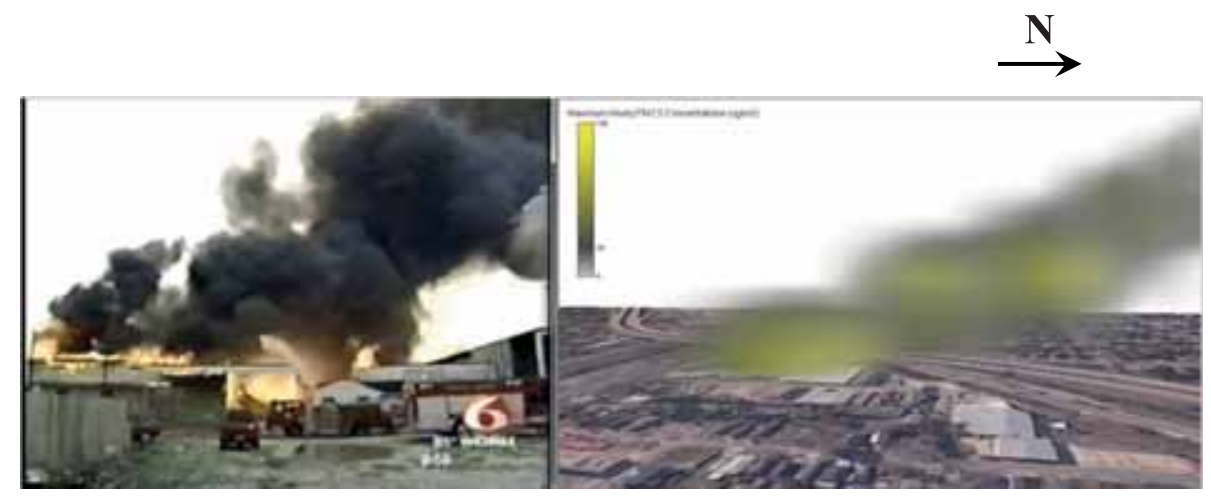

Figure 8: News footage of the fire (left) and ALOFT-FT output (right).

\section{CALIBRATION TO ALOFT-FT}

ALOFT-FT is an advanced fire model that is designed to simulate all of the dynamics of a fire, but it is limited in terms of user inputs and outputs. EPA-approved air quality models like ISCST3 and AERMOD are much more flexible to use; but, they have not been designed to address the complexity of fire plume dynamics at the source. We chose to combine the accuracy of ALOFT-FT with the flexibility of ISCST3/AERMOD and calibrated these models to ALOFT-FT by following these three steps:

1. Run ALOFT-FT with the best available data

2. Record the plume centerline surface concentrations in ALOFT-FT

3. Construct a source and emission scenario in ISCST3/AERMOD that produces similar centerline surface concentrations as ALOFT-FT. 


\section{ISC CALIBRATION TO ALOFT-FT}

By following these calibration steps for ISCST3, we produced the following scenario that approximates the centerline concentrations of ALOFT-FT:

- The $\mathrm{PM}_{2.5}$ emission rate for the period 7:30-8:30 PM is $0.00056 \mathrm{~g} / \mathrm{m}^{2}$-s.

- A circular area source is chosen with a base elevation of $0 \mathrm{~m}$ and release height of $3.3 \mathrm{~m}$. 20 vertices are adopted with a radius of $24.25 \mathrm{~m}$ yielding an area of $1,848 \mathrm{~m}^{2}$, which is the same value as in ALOFT-FT. The initial vertical standard deviation of the concentration distribution $\left(\sigma_{\mathrm{z}}\right)$ is $1.5 \mathrm{~m}$.

Figure 9 shows the area source and downwind receptors used to approximate the ALOFT-FT centerline concentrations, and Fig. 10 compares the centerline concentrations of ISCST3 and ALOFT-FT. The ISCST3 calibrated emission rate is only about $6 \%$ of the ALOFT-FT emission rate; therefore, a rule-of-thumb for simulating emissions from large wood fires using ISCST3 is that only $6 \%$ or less of the emissions are expected to impact the surface, while $94 \%$ or more of the emissions remain aloft and do not impact the surface.

\subsection{Comparison with local measurements and levels of concern}

The City Park DEQ station measured $7.9 \mu \mathrm{g} / \mathrm{m}^{3}$ of $\mathrm{PM}_{2.5}$ on May 14,2004 , and measured $7.7 \mu \mathrm{g} / \mathrm{m}^{3}$ of $\mathrm{PM}_{2.5}$ on the previous day of May 13, 2004 [6]. We will assume that $8 \mu \mathrm{g} / \mathrm{m}^{3}$ is a local background level of $\mathrm{PM}_{2.5}$ during this two-day period. The locations of the City Park station and the Warehouse Fire are shown in Fig. 11. Contours of surface $\mathrm{PM}_{2.5}$

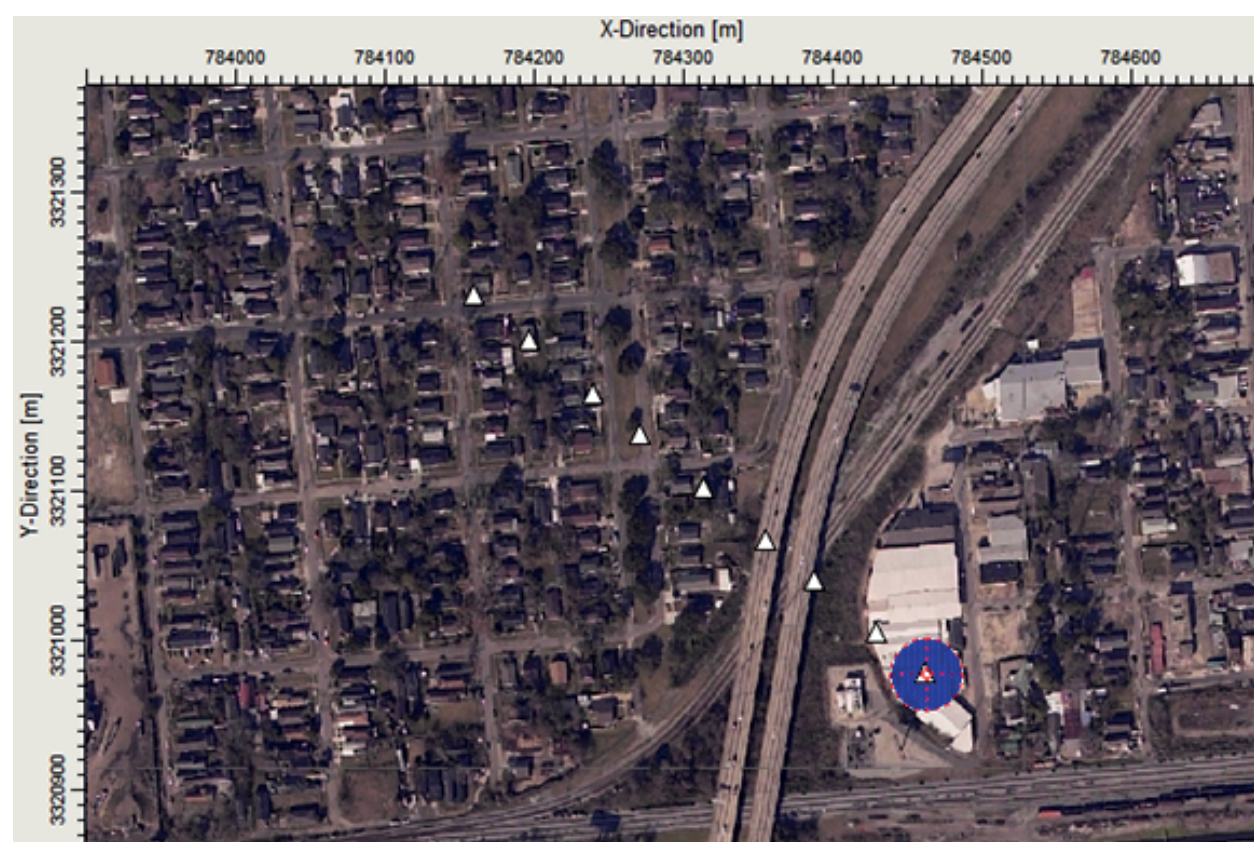

Figure 9: Area source (circle) and 9 surface receptors (triangles) in ISCST3. 


\section{Centerline Surface Concentrations}

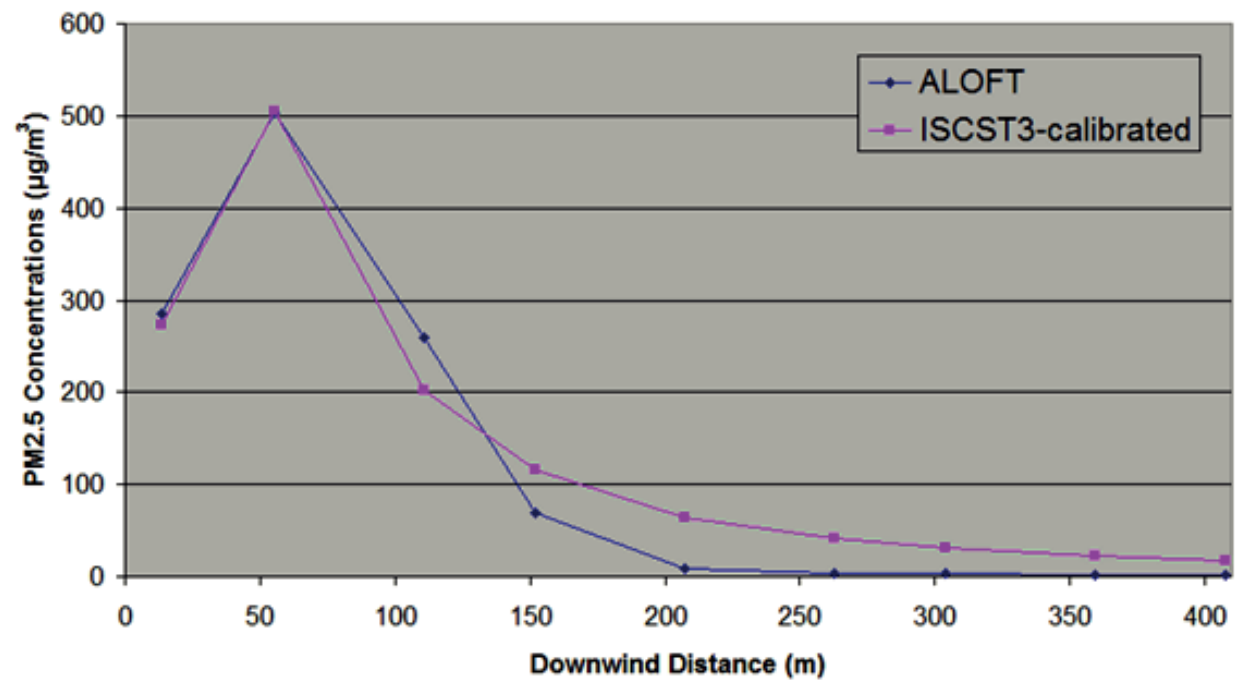

Figure 10: Centerline concentrations of ALOFT-FT and ISCST3.

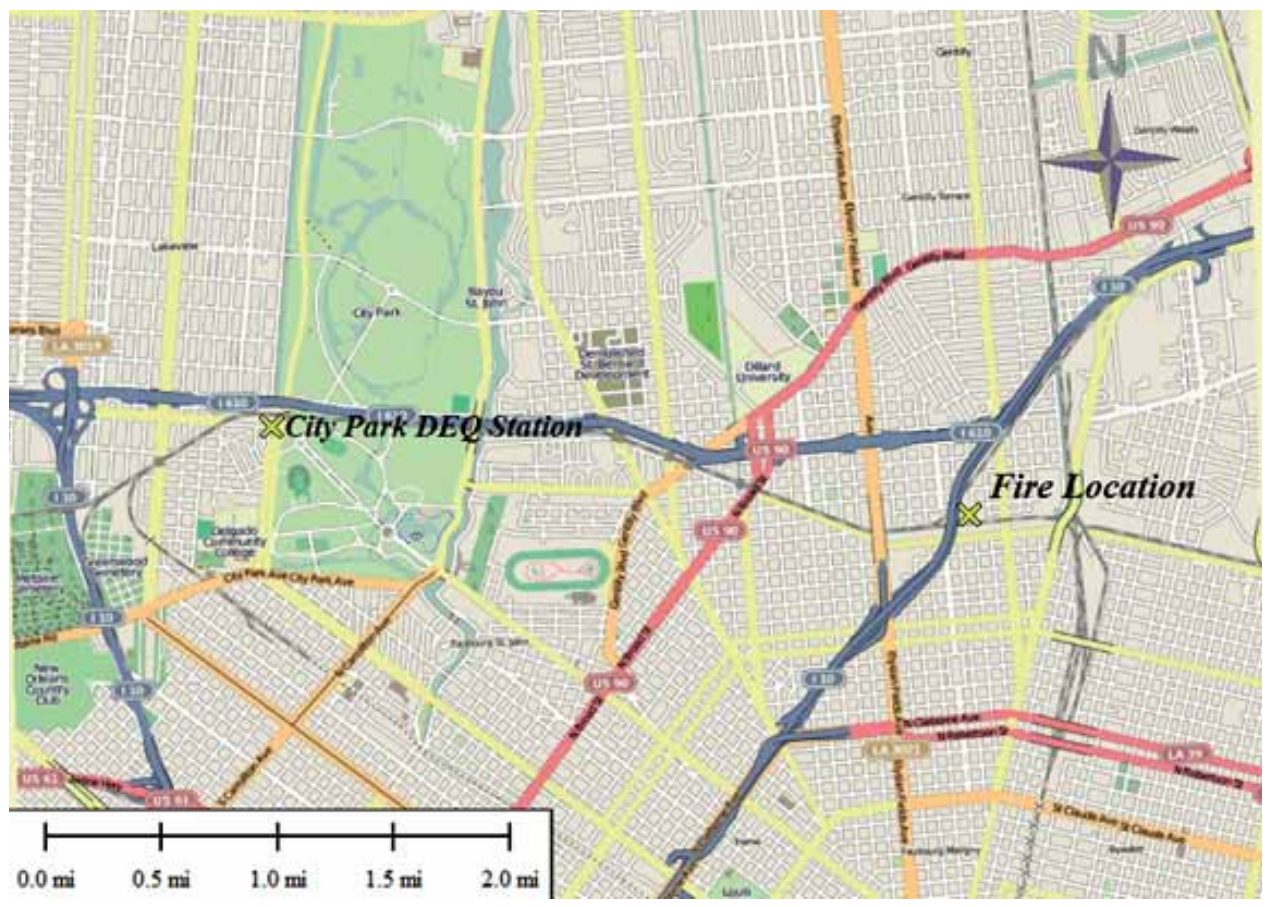

Figure 11: Locations of the fire and the nearest air quality monitoring station (City Park). 


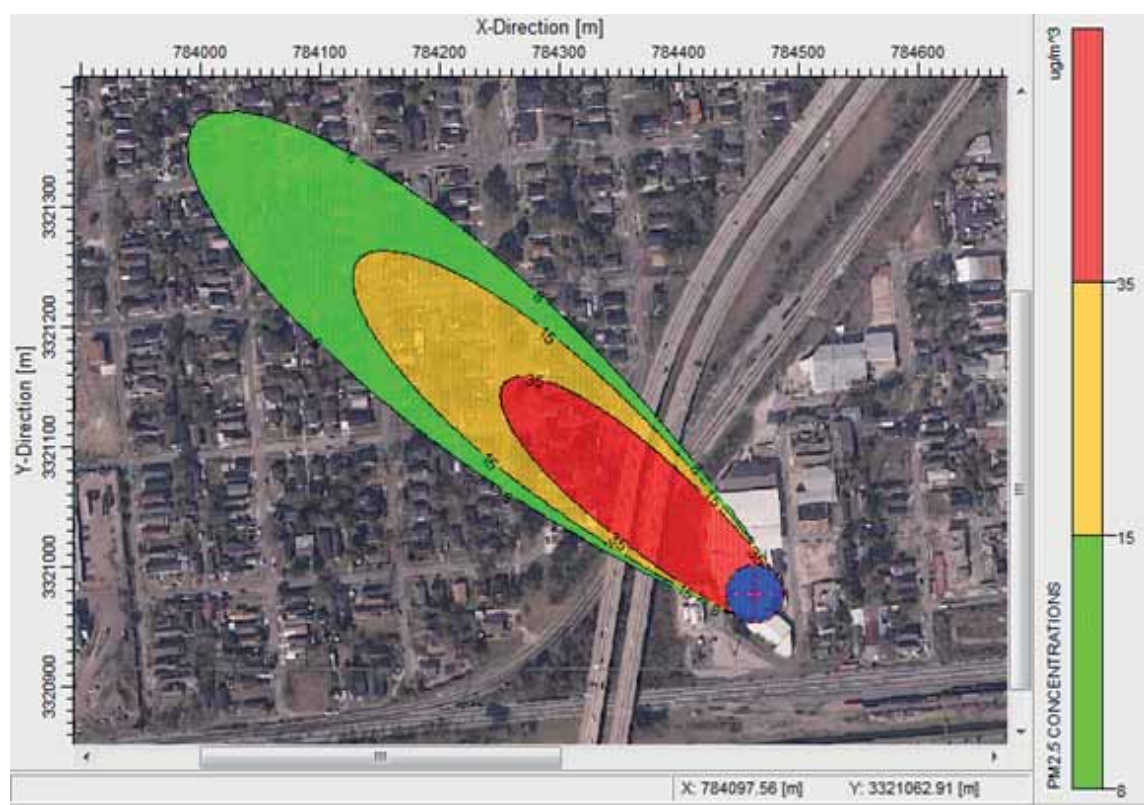

Figure 12: Calibrated ISCST3 output (Coordinate System is UTM Zone 15N, WGS-84).

concentrations from the calibrated ISCST3 output are shown in Fig. 12. The three contours correspond to the 'background' level of $8 \mu \mathrm{g} / \mathrm{m}^{3}$, the annual NAAQS standard of $15 \mu \mathrm{g} / \mathrm{m}^{3}$, and the 24-hour NAAQS standard of $35 \mu \mathrm{g} / \mathrm{m}^{3}$ [7].

Figure 12 shows that the local background level of $\mathrm{PM}_{2.5}\left(8 \mu \mathrm{g} / \mathrm{m}^{3}\right)$ is exceeded within 600 meters downwind during the hour of highest emissions. Also, the annual and 24-hour standards are exceeded within 430 meters and 270 meters respectively.

\section{AERMOD CALIBRATION TO ALOFT-FT}

By repeating the calibration steps for AERMOD, we produced the following scenario that approximates the centerline concentrations of ALOFT-FT:

- The calibrated $\mathrm{PM}_{2.5}$ emission rate for the period 7:30-8:30 PM is $0.0008 \mathrm{~g} / \mathrm{m}^{2}-\mathrm{s}$.

- A circular area source is chosen with a base elevation of $0 \mathrm{~m}$ and a release height of $5.5 \mathrm{~m}$. 20 vertices are adopted with a radius of $24.25 \mathrm{~m}$ yielding an area of $1,848 \mathrm{~m}^{2}$, which is the same value as in ALOFT-FT. The initial vertical standard deviation of the concentration distribution $\left(\sigma_{\mathrm{z}}\right)$ is $2 \mathrm{~m}$.

For the AERMOD scenario, we used the same source and receptors shown in Fig. 9. Figure 13 compares the centerline concentrations of AERMOD and ALOFT-FT. The AERMOD calibrated emission rate is only about $8 \%$ of the ALOFT-FT emission rate; therefore, a ruleof-thumb for simulating emissions from large wood fires using AERMOD is that only $8 \%$ or less of the emissions are expected to impact the surface, while $92 \%$ or more of the emissions remain aloft and do not impact the surface. 


\section{Centerline Surface Concentrations}

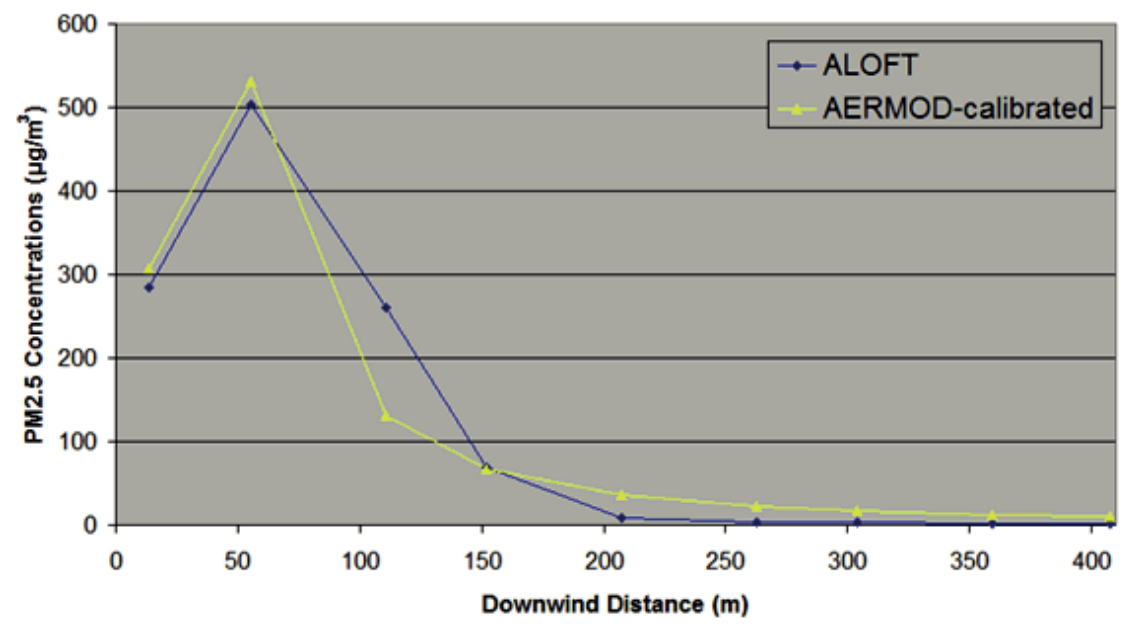

Figure 13: Centerline concentrations of ALOFT-FT and AERMOD.

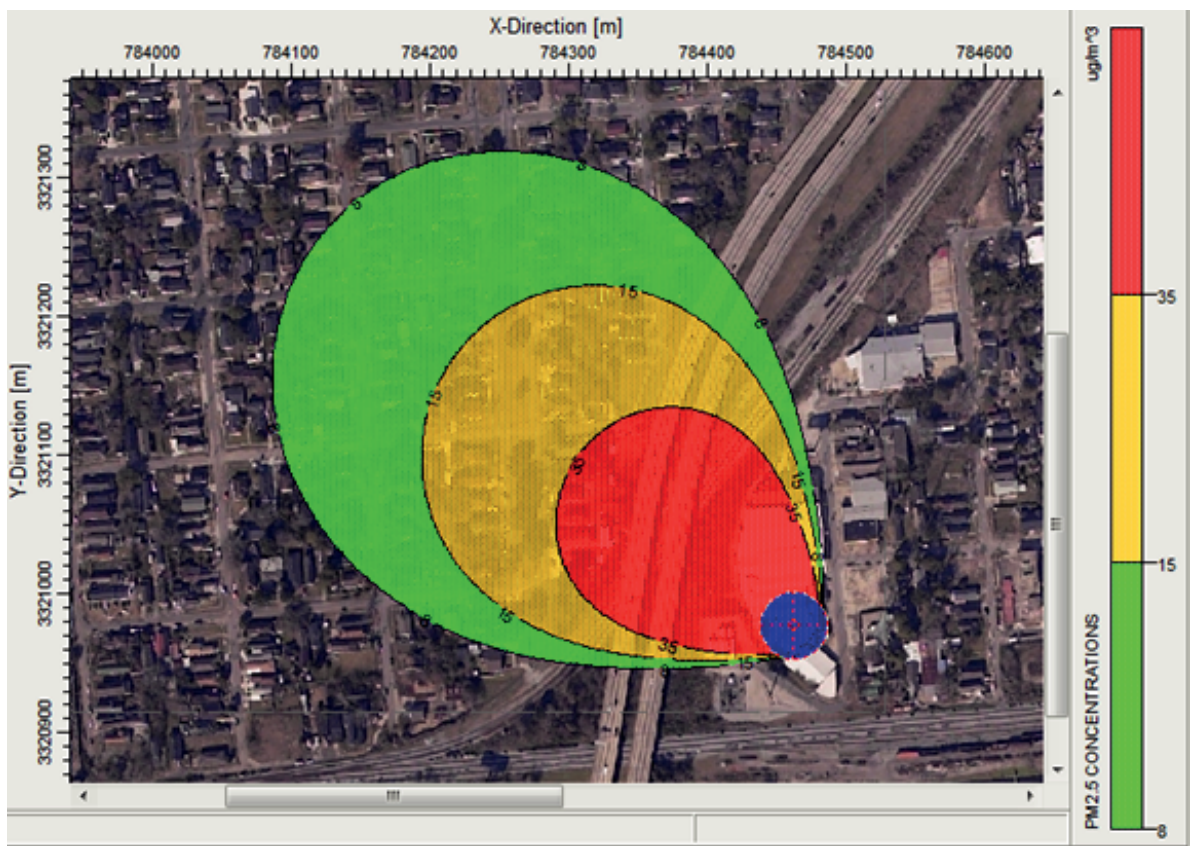

Figure 14: Calibrated AERMOD output (coordinate system is UTM Zone 15N, WGS-84).

Figure 14 shows that AERMOD simulates concentrations greater than the local background level of $\mathrm{PM}_{2.5}\left(8 \mu \mathrm{g} / \mathrm{m}^{3}\right)$ within 445 meters downwind during the hour of highest emissions. The Annual and 24-hour standards are exceeded within 315 meters and 200 meters respectively. 


\section{SUMMARY AND CONCLUSIONS}

$\mathrm{PM}_{2.5}$ emissions from a warehouse fire in New Orleans were computed using a combination of models to develop the best emission scenario based on the available data and the models' fidelity. The computations involved the following steps:

- The development of fire scenario in the warehouse, which involves the development of a time distribution of the fire burning rate and emissions, an estimate of the wood burned in the fire, an estimate of the pollutants' emissions using an emission factor.

- Calibrations of dispersion models, AERMOD and ISCST3, using a fire plume model, ALOFT-FT, which enabled the coupling of a more accurate source model with more flexible input models.

The resulting model enabled a robust estimate of pollutants' dispersion around the Arts Street fire. Additional recommendations follow:

- When studying the surface air quality impact of large fires, it is useful to think of the smoke plume as a combination of a hot upper plume that stays aloft and a cooler lower plume that impacts the ground.

- For a large wood fire, the upper vs. lower plume emissions are about $94 \%$ vs. $6 \%$ for ISCST3 and $92 \%$ vs. $8 \%$ for AERMOD. Determining a reasonably accurate estimate of these proportions, expectedly, has a significant impact on the ground pollutants' concentrations in the immediate vicinity of the fire and far downwind of the fire.

- For hotter fires (e.g. oil, natural gas), we would expect the hot upper plume to exceed the larger percentages listed above for a wood fire. Similarly, we would expect the lower plume percentages to also be lower than the smaller percentages above.

- The plume proportions for ISCST3 and AERMOD are very similar, and any differences are probably due to the nature of these two models. Figs 12 and 14 show how different the outputs are: ISCST3 has a longer, narrower plume than AERMOD for the same weather conditions. This occurs because ISCST3 computes atmospheric dispersion based on the older Pasquill scheme [8], while AERMOD uses a more current understanding of micrometeorology and dispersion.

\begin{tabular}{|c|c|}
\hline AERMOD & $\begin{array}{l}\text { ACRONYMS AND SYMBOLS } \\
\text { American Meteorological Society/Environmental Protection Agency } \\
\text { Regulatory Model Improvement Committee Dispersion } \underline{\text { Model }} \\
\text { http://www.epa.gov/ttn/scram/dispersion_prefrec.htm\#aermod }\end{array}$ \\
\hline ALOFT-FT & $\begin{array}{l}\text { A Large Outdoor Fire Plume Trajectory Model - Flat Terrain } \\
\text { http://www.fire.nist.gov/aloft/ }\end{array}$ \\
\hline BTU & British Thermal Unit \\
\hline DEQ & $\begin{array}{l}\text { Louisiana Department of Environmental Quality } \\
\text { http://www.deq.louisiana.gov/ }\end{array}$ \\
\hline EPA & $\begin{array}{l}\text { United States Environmental Protection Agency } \\
\text { http://www.epa.gov/ }\end{array}$ \\
\hline $\mathrm{g} / \mathrm{m}^{2}-\mathrm{s}$ & $\begin{array}{l}\text { Grams per square meter per second } \\
\text { (i.e., grams emitted from each square meter in one second) }\end{array}$ \\
\hline
\end{tabular}


HHV $\quad$ Higher $\underline{\text { Heating Value }}$

ISCST3 Industrial $\underline{\text { Source }} \underline{\text { Complex }}-\underline{\text { Shhort }}$ Term Dispersion Model ver. 3 http://www.epa.gov/ttn/scram/dispersion_alt.htm\#isc3

MMBTU $\quad 1,000,000 \mathrm{BTU}$

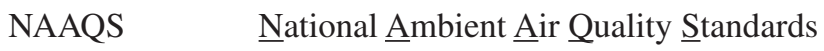
http://www.epa.gov/ttn/naaqs/

NIST $\quad \underline{\text { National }} \underline{\text { Institute of } \underline{S} \text { tandards and Technology }}$ http://www.nist.gov/

$\mathrm{PM}_{2.5} \quad$ Particulate $\underline{\text { Matter with a diameter of } 2.5 \text { microns or smaller }}$

$\sigma_{\mathrm{z}} \quad$ Vertical standard deviation of the concentration distribution

\section{REFERENCES}

[1] AP-42 Team - Emission Factor and Inventory Group. September 2003. Compilation of Air Pollutant Emission Factors, Vol. I., Chapter 1.6. U.S. Environmental Protection Agency, Research Triangle Park, North Carolina, USA. available at http://www.epa. gov/ttn/chief/ap42/index.html

[2] KNEW Meteorological Data (New Orleans Lakefront Airport), available at http:// www.wunderground.com/history/airport/KNEW/2004/5/14/DailyHistory.html?req city $=$ NA\&req_state $=$ NA\&req_statename $=$ NA\& \& theprefset=SHOWMETAR $\&$ thepref value $=1 \&$ format $=1$

[3] Rehm, R.G., Hamins, A., Baum, H.R., McGrattan, K.B. \& D.D. Evans. July 2002. Community-Scale Fire Spread. NISTIR 6891, National Institute of Standards and Technology, Gaithersburg, Maryland, USA. available at http://gisceu.net/PDF/U571.pdf

[4] SIL Radiosonde data (Slidell Airport), available at http://weather.uwyo.edu/cgi-bin/sou nding? region=naconf $\&$ TYPE $=$ TEXT:LIST $\&$ YEAR $=2004 \& M O N T H=05 \& F R O M=15$ $00 \& \mathrm{TO}=1500 \& \mathrm{STNM}=72233$

[5] WDSU Station News Footage in New Orleans, available at http://envirocomp.com /caps/projects/artsst/v1.html

[6] DEQ Air Quality Measurements for New Orleans City Park, available at http://www .deq.louisiana.gov/portal/tabid/2420/Default.aspx

[7] EPA National Ambient Air Quality Standards (NAAQS), available at http://www.epa .gov/air/criteria.html

[8] Pasquill F., The estimation of the dispersion of windborne material. Meteor. Mag., 90, pp. 33-49, 1961. 